\title{
PENYUSUNAN STRATEGI BISNIS DAN STRATEGI OPERASI USAHA KECIL DAN MENENGAH PADA PERUSAHAAN KONVEKSI SCISSORS DI SURABAYA
}

\author{
MOCHAMAD AMMAR FARUQ \\ (ammarfarug04@gmail.com) \\ INDRIANAWATI USMAN \\ (indrianawati@gmail.com) \\ Departemen Manajemen Fakultas Ekonomi dan Bisnis Universitas Airlangga
}

\begin{abstract}
The development of globalization era gives us tighter business competition in many sector including UKM (Usaha Kecil dan Menengah). A company tends to make a good business and strategic operation to gives a positive effect for all UKM doers to face business competition. This case is very interesting to be researched and taught how business and operation strategic arrangement provide high competitiveness factor towards the company.
\end{abstract}

This research included as descriptive-explorative qualitative research. This research did not need any theory or hypotheses but only use some prepared questions as a guide to get primary data about information which is the first data that required for this research (Moleong: 1998). This research object is one of the UKM convection called Scissors Convection on jl. Simorejo 6, Surabaya. Data analysis technique in this research are using content analysis and matrixes as the instrument. Matrixes that used in this data analysis are External Factor Evaluation (EFE), Internal Factor Evaluation (IFE), Competitive Profile Matrix (CPM), Strengths-Weaknesses-Opportunities-Threats (SWOT), Grand Strategy, and Quantitative Strategic Planning Matrix (QSPM). Also, triangulation technique as source consistency experiment towards data and operation strategy based on Roger $G$. Schroeder's Operation Management.

Result of this research proved that the appropriate business strategy for Scissors Convection are product development strategy for variation and product design while the best operation strategy is product innovator strategy.

Keywords: UKM (Usaha Kecil dan Menengah), strategy arrangement, business strategy, operation strategy, Scissors Convection

\section{PENDAHULUAN}

Keberadaan UKM di Indonesia tidak bisa dipungkiri adalah suatu badan usaha yang sangat membantu pertumbuhan ekonomi Indonesia. Telah kita diketahui, sebelumnya Indonesia pernah mengalami krisis moneter pada tahun 1997-1998 yang mengakibatkan 


\section{Mochamad Ammar Faruq Indrianawati Usman}

ketidakstabilan perekonomian saat itu. Banyak pengusaha-pengusaha yang kolaps bahkan bangkrut dan sektor perbankan yang menjadi penopang bagi pertumbuhan ekonomi nasional turut 'ambruk', khususnya bank-bank swasta nasional kecil. Sedangkan UKM tetap bisa bertahan bahkan bisa menembus pasar yang selama ini dikuasai perusahaan besar.

Menurut (Basri, 2003 dalam Arif, 2009) UKM di Indonesia dapat bertahan di masa krisis ekonomi disebabkan oleh 4 hal yaitu: (1) sebagian UKM menghasilkan barang-barang konsumsi (consumer goods), khususnya yang tidak tahan lama, (2) mayoritas UKM lebih mengandalkan pada non-banking financing dalam aspek pendanaan usaha, (3) pada umumnya UKM melakukan spesifikasi produk yang ketat, dalam arti hanya memproduksi barang atau jasa tertentu saja, dan (4) terbentuknya UKM baru sebagai akibat dari banyaknya pemutusan hubungan kerja di sektor formal.

Kinerja UKM di Indonesia dapat ditinjau dari beberapa aspek, yaitu: (1) nilai tambah, (2) unit usaha, tenaga kerja dan produktivitas, (3) nilai ekspor.

1) Nilai Tambah

Kinerja perekonomian di Indonesia yang diciptakan oleh UKM pada tahun 2011 terhadap penciptaan PDB nasional menurut harga berlaku tercatat sebesar Rp 7.427.086,1 milyar atau 57,94 persen, kontribusi Usaha Mikro (UMi) tercatat sebesar Rp 2.579.388,4 triliun atau 34,73 persen dan Usaha kecil (UK) sebesar Rp 722.012,8 milyar atau 9,72 persen. Sedangkan Usaha Menengah (UM) tercatat sebesar Rp 1.002.170,3 milyar atau 13,49 persen dari total PDB nasional, selebihnya adalah Usaha Besar (UB) yaitu Rp 3.123.514,6 milyar atau 42,06 persen.

2) Unit usaha dan tenaga kerja

Perkembangan jumlah populasi UMKM periode 2011-2012 mengalami peningkatan sebesar 2,41 persen yaitu dari 55.211.396 unit pada tahun 2011 menjadi 56.539.560 unit pada tahun 2012. UMKM merupakan pelaku usaha terbesar dengan persentasenya sebesar 99,99 persen dari total pelaku usaha nasional pada tahun 2011.

Pada tahun 2012, UMKM mampu menyerap tenaga kerja sebesar 107.657.509 orang atau 97,16 persen dari total penyerapan tenaga kerja yang ada, jumlah ini meningkat sebesar 5,83 persen atau 5.935.051 orang dibandingkan tahun 2011. Kontribusi Usaha Mikro (UMi) tercatat sebanyak 99.859 .517 orang atau 90,12 persen dan Usaha Kecil (UK) sebanyak 4.535.970 orang atau 4,09 persen. Sedangkan Usaha Menengah (UM) tercatat sebanyak 3.262 .023 orang atau 2,94 persen.

3) Ekpor UKM

Hasil produksi UKM yang diekspor ke luar negeri berdasarkan kontribusi UMKM terhadap pembentukan total nilai ekspor non migas pada tahun 2011, dengan tercapainya angka sebesar Rp 187,441,8 milyar atau 16,44 persen dari total nilai ekspor non migas. Kontribusi Usaha Mikro (UMi) tercatat sebesar Rp 17,249,3 milyar atau 1,51 persen dan UK tercatat 


\section{Jurnal Manajemen Teori dan Terapan \\ Tahun 7. No. 3, Desember 2014}

sebesar Rp 39,311,7 milyar atau 3,45 persen. Sedangkan UM tercatat sebesar Rp 130,880,8 milyar atau 11,48 persen, selebihnya adalah UB tercatat sebesar Rp 953,009,3 milyar atau 83,56 persen.

Peran UMKM terhadap pembentukan total nilai ekspor non migas pada tahun 2012 mengalami penurunan sebesar Rp 20.815,4 milyar atau 11,10 persen. Pada tahun 2012 tercatat sebesar Rp 166.626,5 milyar atau 14,06 persen, kontribusi Usaha Mikro (UMi) tercatat sebesar Rp 15.235,2 milyar atau 1,29 persen dan UK tercatat sebesar Rp 32.508,8 milyar atau 2,74 persen. Sedangkan UM sebesar Rp 32.508,8 milyar atau 10,03 persen selebihnya adalah UB sebesar Rp 1.018.764,5 milyar atau 85,94 persen (www.depkop.go.id) diakses pada tanggal 5 Maret 2014

Usaha Kecil dan Menengah (UKM) sering kali menghadapi beberapa permasalahan, antara lain terbatasnya akses Koperasi dan UMKM kepada sumberdaya produktif terutama terhadap bahan baku, permodalan, teknologi, sarana pemasaran serta informasi pasar. (Renstra Kemenkop Rl 2014).

Berkembangnya era globalisasi saat ini memberikan dampak persaingan bisnis yang semakin ketat termasuk pada sektor Usaha Kecil dan Menengah (UKM). Keberadaan Sektor Usaha Kecil dan Menengah yang dominan sebagai pelaku ekonomi nasional juga merupakan subyek vital dalam pembangunan, khususnya dalam rangka perluasan kesempatan berusaha bagi wirausaha baru dan penyerapan tenaga kerja serta menekan angka pengangguran (pro job) serta pro environment. (Renstra Kemenkop RI tahun 20122014).

Jenis perusahaan terutama yang berbasis UKM tentu harus mempunyai strategi bisnis dan strategi operasi yang tepat dan efisien dalam menjalankan proses bisnisnya agar tidak melenceng dan dapat berjalan sesuai tujuan awal perusahaan. Strategi yang dijalankan mulai dari pengembangan produk yang didasarkan pada ide-ide kreatif dan original sehingga menjadi pembeda dan mempunyai ciri khas dibanding produk dari kompetitor, proses internal perusahaan itu sendiri hingga strategi pemasaran agar produk tersebut.

Peningkatan keunggulan kompetitif melalui prestasi operasi membutuhkan suatu tanggapan strategis dalam suau fungsi operasi (Schroeder 1989). Strategi yang diterapkan dengan baik dan tepat akan mengantisipasi masalah dan kesempatan di masa mendatang pada kondisi perusahan yang berubah dengan cepat, sehingga perusahaan dapat beradaptasi dengan baik dengan lingkungan usaha yang dinamis seperti saat ini.

Berdasarkan kondisi diatas, perlu adanya upaya yang harus dilakukan oleh Konveksi Scissors dalam perumusan strategi bisnis dan operasinya terhadap terhadap pengembangan kinerja UKM dengan cara melakukan perumusan strategi bisnis dan strategi operasi yang 


\section{Mochamad Ammar Faruq Indrianawati Usman}

terintegrasi dengan baik sehingga nantinya dapat diimplementasikan oleh Konveksi Scissors dan diharapkan sesuai dengan karakteristik UKM di Indonesia.

\section{RUMUSAN MASALAH}

1. Bagaimanakah strategi bisnis yang tepat bagi Konveksi Scissors?

2. Bagaimanakah strategi operasi yang mendukung strategi bisnis bagi Konveksi Scissors? TUJUAN PENELITIAN

1. Merumuskan alternatif strategi bisnis yang tepat bagi Konveksi Scissors.

2. Merumuskan alternatif strategi operasi yang mendukung strategi bisnis bagi Konveksi Scissors.

\section{TINJAUAN PUSTAKA}

\section{PENGERTIAN MANAJEMEN}

Menurut Daft (2002:8), manajemen adalah pencapaian sasaran-sasaran organisasi dengan cara yang efektif dan efisien melalui perencanaan, pengorganisasian, kepemimpinan dan pengendalian sumber daya organisasi.

\section{PENGERTIAN STRATEGI}

Menurut David (2012), strategi adalah sarana bersama dengan tujuan jangka panjang yang akan hendak dicapai. Strategi bisnis bisa berupa perluasan geografis, diversifikasi, akusisi, pengembangan produk, penetrasi pasar, rasionalisasi karyawan, divestasi, likuidasi dan usaha patungan atau joint venture.

Menurut Barney dan Hesterly (2008), strategi dijelaskan sebagai sebuah teori tentang bagaimana cara perusahaan meraih keunggulan-keunggulan kompetitif (Competitive Advantages).

Menurut Hitt (2011), strategi merupakan sebuah rangkaian yang terpadu dan terkoordinasi dari komitmen dan tindakan yang dirancang untuk mengeksplotasi kompetensi utama dan meraih keunggulan kompetitif.

Strategi memberi jawaban bagi pihak manajemen mengenai bagaimana cara mencapai tujuan perusahaan dan bagaimana caranya untuk mencapai misi organisasi dan visi strategis. Pembuatan strategi adalah tentang bagaimana mencari target-target, bagaimana bersaing dengan para kompetitor, bagaimana mencapai keunggulan bersaing yang berkepanjangan, bagaimana membuat visi strategis manajemen sebagai sebuah kenyataan bagi suatu perusahaan

\section{MANAJEMEN STRATEGIK}

Menurut David (2012), manajemen strategik dapat didefinisikan sebagai seni dan pengetahuan dalam merumuskan, mengimplementasi, serta mengevaluasi keputusan lintas fungsional yang memungkinkan organisasi mencapai tujuannya. Sebagai definisi ini menyiratkan, manajemen strategis berfokus pada mengintegrasikan manajemen, 


\section{Jurnal Manajemen Teori dan Terapan \\ Tahun 7. No. 3, Desember 2014}

pemasaran, keuangan / akuntansi, produksi / operasi, sistem penelitian dan pengembangan, dan informasi untuk mencapai keberhasilan organisasi.

Dapat disimpulkan bahwa Manajemen strategis adalah suatu proses manajemen di dalam suatu perusahaan yang berguna dalam merumuskan keputusan lintas-fungsional yang menghasilkan strategi untuk mencapai tujuan yang telah ditetapkan.

Menurut Hariadi (2003), manajemen strategik adalah suatu proses yang dirancang secara sistematis oleh manajemen untuk merumuskan strategi, menjalankan strategi dan mengevaluasi strategi dalam rangka menyediakan nilai-nilai yang terbaik bagi seluruh pelanggan.

\section{PENGERTIAN MODEL LIMA KEKUATAN PORTER}

Menurut David (2009), Porter's Five Force Model digunakan secara luas untuk mengembangkan strategi dalam banyak industri. Intensitas persaingan antar perusahaan sangat beragam di berbagai industri. Intensitas persaingan tertinggi terdapat pada industri dengan tingkat pengembalian rendah.

Menurut Porter (2008), suatu industri dapat dilihat sebagai kombinasi atas lima kekuatan:

1. Persaingan antar perusahaan sejenis

Intensitas persaingan di antara perusahaan sejenis yang bersaing cenderung meningkat karena jumlah pesaing semakin bertambah, pesaing semakin seragam dalam hal ukuran dan kemampuan, permintaan untuk produk industri menurun dan karena pemotongan harga menjadi semakin umum. Persaingan juga meningkat ketika pelanggan dapat berpindah merek dengan mudah, hambatan untuk meninggalkan pasar tinggi, biaya tetap tinggi, produk mudah rusak, perusahaan pesaing berbeda dalam hal strategi, tempat mereka berasal dan budaya serta ketika merger dan akuisisi menjadi umum dalm suatu industri. Ketika persaingan antar perusahaan sejenis semakin intensif, laba perusahaan menurun, dalam beberapa kasus bahkan membuat suatu industri menjadi sangat tidak menarik.

\section{Kemungkinan masuknya pesaing baru}

Ketika perusahaan baru dapat dengan mudah masuk ke dalam industri tertentu, intensitas persaingan antar perusahaan meningkat. Tetapi hambatan untuk masuk, dapat mencakup kebutuhan untuk mencapai skala ekonomi dengan cepat, kebutuhan untuk mendapatkan teknologi dan pengetahuan khusus, kurangnya pengalaman, tingginya kesetiaan pelanggan, kuatnya preferensi merek, besarnya kebutuhan akan modal, kurangnya jalur distribusi yang memadai, peraturan pemerintah, tarif, kurangnya akses terhadap barang mentah, kepemilikan paten, lokasi yang kurang menguntungkan, serangan balasan dari perusahaan yang sudah mapan, dan potensi kejenuhan pasar.

Disamping berbagai hambatan masuk, perusahaan baru kadang-kadang memasuki suatu bisnis dengan produk berkualitas lebih tinggi, harga lebih rendah, dan sumber daya 


\section{Mochamad Ammar Faruq Indrianawati Usman}

pemasaran lebih besar. Dengan demikian, tugas penyusun strategi adalah untuk mengidentifikasi perusahaan yang berpotensi masuk ke pasar, memonitor strategi pesaing baru, membuat serangan balasan apabila dibutuhkan serta memanfaatkan kekuatan dan peluang yang ada saat ini.

\section{Potensi Pengembangan Produk Substitusi}

Tekanan kompetisi yang berasal dari produk substitusi meningkat sejalan dengan menurunnya harga relatif dari produk substitusi dan dengan biaya konsumen untuk beralih ke produk lain menurun. Cara terbaik untuk mengukur kekuatan kompetitif produk substitusi adalah dengan memantau pangsa pasar yang diperoleh oleh produk-produk tersebut, juga dengan memantau rencana perusahaan untuk meningkatkan kapasitas dan penetrasi pasar.

\section{Kekuatan Tawar Menawar Pemasok}

Kekuatan tawar-menawar pemasok mempengaruhi intensitas persaingan dalam suatu industri, khususnya ketika ada sejumlah besar pemasok, ketika hanya ada sedikit barang substitusi yang cukup bagus, atau ketika biaya untuk mengganti bahan baku sangat mahal. Perusahaan dapat menjalankan strategi integrasi ke belakang untuk mendapatkan kendali atau kepemilikan dari pemasok. Strategi ini efektif khususnya ketika pemasok tidak dapat diandalkan, terlalu mahal atau tidak mampu memenuhi kebutuhan perusahaan secara konsisten. Perusahaan umumnya dapat menegosiasikan syarat yang lebih menguntungkan bagi pemasok ketika integrasi ke belakang menjadi strategi yang digunakan secara umum di antara perusahaan-perusahaan yang bersaing dalam satu industri.

\section{Kekuatan Tawar Menawar Konsumen}

Ketika konsumen terkonsentrasi atau besar jumlahnya, atau membeli dalam jumlah besar, kekuatan tawar-menawar mereka menjadi kekuatan utama yang mempengaruhi intensitas persaingan dalam suatu industri. Perusahaan pesaing mungkin menawarkan garansi yang lebih panjang atau jasa khusus untuk mendapatkan kesetiaan pelanggan ketika kekuatan tawar-menawar konsumen cukup besar. Kekuatan tawar-menawar konsumen juga lebih tinggi ketika yang dibeli adalah produk standar atau tidak terdiferensiasi. Ketika kondisi seperti ini, konsumen sering kali dapat bernegosiasi tentang harga jual, cakupan garansi dan paket asesoris hingga ke tingkat yang lebih tinggi.

\section{PERUMUSAN STRATEGI BISNIS}

Menurut David (2009), teknik analisis dalam perumusan strategi bisnis dapat dilakukan melalui tiga tahap, yaitu tahap input (EFE, IFE dan CPM), tahap pencocokan (TOWS, IE dan Grand Strategy) dan tahap keputusan (QSPM)

\section{USAHA KECIL DAN MENENGAH}

1. Usaha Mikro adalah usaha produktif milik orang perorangan dan/atau badan usaha perorangan yang memenuhi kriteria Usaha Mikro sebagaimana diatur dalam UndangUndang ini. 
2. Usaha Kecil adalah usaha ekonomi produktif yang berdiri sendiri, yang dilakukan oleh orang perorangan atau badan usaha yang bukan merupakan anak perusahaan atau bukan cabang perusahaan yang dimiliki, dikuasai, atau menjadi bagian baik langsung maupun tidak langsung dari usaha menengah atau usaha besar yang memenuhi kriteria Usaha Kecil sebagaimana dimaksud dalam Undang-Undang ini.

3. Usaha Menengah adalah usaha ekonomi produktif yang berdiri sendiri, yang dilakukan oleh orang perseorangan atau badan usaha yang bukan merupakan anak perusahaan atau cabang perusahaan yang dimiliki, dikuasai, atau menjadi bagian baik langsung maupun tidak langsung dengan Usaha Kecil atau usaha besar dengan jumlah kekayaan bersih atau hasil penjualan tahunan sebagaimana diatur dalam Undang-Undang ini.

4. Usaha Besar adalah usaha ekonomi produktif yang dilakukan oleh badan usaha dengan jumlah kekayaan bersih atau hasil penjualan tahunan lebih besar dari usaha menengah, yang meliputi usaha nasional milik negara atau swasta, usaha patungan, dan usaha asing yang melakukan kegiatan ekonomi di Indonesia.

Sumber: UU No.20 2008 Tentang Usaha Kecil, Mikro, dan Menengah

\section{STRATEGI OPERASI}

Krawjesky dan Ritzman (2002) mendefinisikan strategi operasi sebagai dimensi yang harus dimiliki oleh sistem produksi suatu perusahaan untuk mendukung permintaan pasar agar perusahaan tersebut Sedangkan Flahtery (1996) mendefinisikan strategi operasi sebagai papan rencana perusahaan atau unit bisnis untuk mengembangkan, memperkenalkan, dan menghasilkan produk agar memuaskan kebutuhan pelanggan lebih baik dari pesaing. Kedua definisi tersebut memuat adanya orientasi pada pelanggan dan senjata bersaing.

Menurut Schroeder (1989) mendefinisikan strategi operasi adalah suatu visi fungsi operasi yang menetapkan keseluruhan arah atau daya dorong untuk pengambilan keputusan. Visi ini harus di integrasikan dengan strategi bisnis dan direfleksikan pada perencanaan formal tapi sering sekali tidak dilakukan. Strategi operasi seharusnya menghasilkan suatu pola pengambilan keputusan operasi yang konsisten dan mengahasilkan keunggulan bersaing bagi perusahaan.

Sehingga dapat disimpulkan bahwa konsep dan definisi strategi operasi adalah sebagai sebuah prosedur pengambilan keputusan perusahaan agar memiliki kepemimpinan dalam aktivitas manufakturing yang didasarkan pada perspektif strategi.

\section{MODEL STRATEGI OPERASI}

Strategi operasi adalah strategi fungsional yang diarahkan oleh strategi bisnis dan akan menghasilkan suatu pola yang konsisten dalam keputusan. Schroeder (1989) menjelaskan hubungan ini empat elemen yang ada yaitu: misi, keunggulan khusus, tujuan, dan kebijakan merupakan inti dari strategi operasi. 


\section{Mochamad Ammar Faruq Indrianawati Usman}

\section{STRATEGI BISNIS DAN PERUSAHAAN}

Schroeder (1989) Strategi perusahaan mendefinisikan dalam bisnis yang seperti apa perusahaan berada. Strategi bisnis mendefinisikan bagaimana bisnis tertentu bersaing. Setiap bisnis perlu menemukan dasar persaingannya sendiri berdasarkan segmen pasar dan produk tertentu yang telah diputuskan untuk dimasuki.

\section{ANALISIS EKSTERNAL DAN INTERNAL PERUSAHAAN}

Schroeder (1989) Dalam merumuskan suatu strategi operasi dan persoalan strategi bisnis, suatu analisis harus dibuat berdasarkan lingkungan eksternal dan internal. Lingkungan eksternal biasanya meliputi persaingan, pelanggan, ekonomi, teknologi dan kondisi sosial. Lingkungan eksternal selain dapat membentuk strategi bisnis dan strategi perusahaan juga dapat membentuk strategi operasi. Suatu analisis lingkungan internal bisanya mengarah pada pengidentifikasian kekuatan dan kelemahan operasi yang ada. Strategi operasi mencoba mengatasi kelemahan dan mengembangkan kekuatan yang ada.

\section{MISI OPERASI}

Schroeder (1989) Misi operasi merupakan elemen pertama dalam empat elemen strategi operasi, mendefinisikan manfaat fungsi dalam hubungannya dengan strategi bisnis dan strategi operasi. Sasaran operasi adalah harga, mutu, pengiriman, dan fleksibilitas. Misi operasi harus menentukan prioritas dari sasaran operasi.

\section{KEUNGGULAN KHUSUS}

Schroeder (1989) Keunggulan khusus operasi adalah operasi yang unggul secara relatif untuk bersaing. Keunggulan khusus ini harus sesuai dengan misi operasi. Keunggulan khusus mengarah pada keunggulan bersaing hingga inti operasi. Operasi dapat menjadi unggul dengan sasaran operasi: harga terendah, mutu tertinggi, pengiriman terbaik, atau fleksibilitas terbesar.

\section{SASARAN OPERASI}

Schroeder (1989) Elemen ketiga dari strategi operasi adalah sasaran. Empat sasaran umum yang mungkin adalah: harga, mutu, pengiriman, dan flesibilitas. Sasaran operasi harus dinyatakan dalam bentuk kuantitatif yang spesifik dan dalam bentuk yang dapat diukur. Sasaran ini diharapkan dapat dicapai dalam jangka waktu yang singkat maupun jangka waktu yang panjang.

\section{KEBIJAKAN OPERASI}

Schroeder (1989) Kebijakan operasi menerangkan bagaimana sasaran operasi akan dicapai. Kebijakan operasi harus dikembangkan untuk setiap kategori keputusan: proses, kapasitas, sediaan, tenaga kerja, dan mutu.

\section{TAKTIK DAN HASIL}


Schroeder (1989) Taktik harus mengikuti perkembangan strategi. Keputusan taktis umumnya dibagi dalam kerangka waktu yang singkat (1 atau 2 tahun) dan dikembangkan untuk menerapkan strategi operasi. hasilnya biasanya diukur pada keadaan yang sama dengan sasaran yang digunakan untuk menentukan apakah suatu strategi dan taktik terlaksana atau tidak. Jika hasilnya tidak memuaskan, manajemen dapat merubah setiap taktik maupun strategi yang mungkin dibutuhkan.

\section{JENIS-JENIS STRATEGI OPERASI}

Strategi pertama adalah strategi produser biaya rendah yang dicirikan oleh produk yang berdaur hidup panjang, pasar peka terhadap harga dan produk standar. Dalam kasus ini , tujuan operasi lebih ditekankan pada harga, sehingga operasi harus dapat menekan biaya dengan melakukan kebijakan-kebijakan seperti: proses teknologi tinggi, biaya tenaga kerja murah, tingkat persediaan rendah, erajat integrasi vertikal tinggi,, serta mutu terjamin.

Strategi yang kedua adalah inovator produk dan pengenalan produk. Menurut Schroeder (1989) strategi ini umumnya dipakai pada produk baru dengan kemungkinan pasar dapat berkembang dan keunggulan diperoleh melalui produk yang superior dan dalam jangka waktu yang singkat.

\section{METODE PENELITIAN}

Dalam penelitian ini, metode penelitian yang digunakan adalah metode kualitatif deskriptifeksploratif. Menurut Universitas Airlangga (2009), pendekatan kualitatif adalah suatu pendekatan penelitian yang menggunakan data berupa kalimat tertulis atau lisan, perilaku, fenomena, peristiwa, pengetahuan atau objek studi. Proses penelitian tersebut memperhatikan konteks studi dengan menitikberatkan pada pemahaman, pemikiran dan persepsi dari peneliti. Hasilnya dapat berupa konsep, teori baru, penemuan baru, pengetahuan aplikatif, solusi praktis dan berbagai kajian atau pemikiran ilmiah.

Adapun metode deskriptif menurut Moleong (1998) dapat diartikan sebagai prosedur pemecahan masalah yang diselidiki dengan menggambarkan atau melukiskan keadaan subyek atau obyek penelitian (seseorang, masyarakat, organisasi dan lain-lain) pada saat sekarang berdasarkan fakta-fakta yang tampak atau sebagaimana adanya. Data yang dikumpulkan dapat berupa kata-kata, gambar atau angka-angka. Data tersebut mungkin berasal dari naskah wawancara, catatan lapangan, foto, video, dokumen pribadi, catatan atau memo dan dokumen resmi lainnya.

Menurut Sugiyono (2006), penelitian deskriptif adalah suatu penelitian yang digunakan untuk menggambarkan atau menganalisis suatu statistik hasil penelitian, tetapi tidak digunakan untuk membuat kesimpulan yang lebih luas (generalisasi/inferensi).

Adapun metode eksploratif menurut Moleong (1998) adalah salah satu metode penelitian yang bersifat mendasar dan bertujuan untuk memperoleh keterangan, informasi, data mengenai hal-hal yang belum diketahui. Karena bersifat mendasar itulah penelitian ini 


\section{Mochamad Ammar Faruq Indrianawati Usman}

disebut eksploratif. Penelitian eksploratif dilakukan tanpa adanya data awal sehingga belum ada gambaran mengenai hal yang akan diteliti. Penelitian ini tidak memerlukan hipotesis atau teori tertentu, tetapi hanya menyiapkan beberapa pertanyaan sebagai penuntun untuk memperoleh data primer berupa keterangan dan informasi yang merupakan data awal yang diperlukan. Metode pengumpulan data primer yang digunakan adalah observasi di lokasi penelitian dan wawancara dengan responden. Responden bisa siapa saja yang dianggap relevan dengan penelitian yang dilakukan.

\section{PROSEDUR PENGUMPULAN DATA}

Data yang akan didapat dalam penelitian ini dapat berupa angka-angka, keterangan tertulis, informasi lisan dan beragam fakta yang berhubungan dengan fokus penelitian yang diteliti. Dalam penelitian ini akan digunakan 2 teknik pengumpulan data, yaitu:

1. Studi Lapangan:

Penelitian secara langsung ke lapangan untuk mendapatkan data dan informasi dari perusahaan. Studi ini bisa dilakukan dengan dua metode yaitu:

a. Wawancara

Untuk mendapatkan data yang diperlukan dalam penelitian, dilakukan sebuah wawancara dengan pihak perusahaan, yang mana dilakukan dengan mewawancarai pemilik usaha yaitu Bapak Hendro, pemasaran Bapak Hendri dan operasional Bapak Hadi.

b. Kuesioner

Untuk menentukan nilai rating dan pembobotan, diperlukan sebuah kuisioner yang akan diberikan kepada pihak terkait dari UKM Konveksi Scissors, yaitu Pemilik, bagian Pemasaran dan bagian Operasional usaha Konveksi Scissors.

\section{Studi Pustaka:}

Penelitian dilakukan dengan mengambil sumber data yang relevan dengan bahan penelitian dari berbagai literatur, baik buku, majalah, jurnal, internet dan sebagainya guna mendukung penelitian ini.

\section{BATASAN PENELITIAN}

1. Obyek penelitian adalah konveksi Scissors.

2. Responden penelitian adalah pemilik, bagian pemasaran dan bagian operasional konveksi Scissors.

3. Model perumusan strategi yang digunakan adalah model perumusan strategi dalam buku Strategic Management oleh Fred R. David.

4. Strategi operasi yang digunakan adalah dalam buku Operation Management oleh Roger G. Schroeder.

\section{TEKNIK ANALISIS}


Menurut David (2009:177), teknik analisis dalam perumusan strategi dapat dilakukan melalui tiga tahap, yaitu tahap input (EFE, IFE dan CPM), tahap pencocokan (TOWS, IE dan Grand Strategy) dan tahap keputusan (QSPM).

1) TAHAP INPUT

a) MATRIKS EFE

Menurut David (2009), matriks EFE memungkinkan untuk meringkas dan mengevaluasi faktorfaktor eksternal perusahaan yang bisa menjadi peluang dan ancaman bagi perusahaan. Faktor-faktor tersebut seperti ekonomi, budaya, demografi, lingkungan, politik, pemerintahan, hukum, teknologi dan kompetitif.

b) MATRIKS IFE

Menurut David (2009), Matriks IFE adalah sebuah alat dipake untuk menyusun faktor internal perusahaan. Matriks ini meringkas dan mengevaluasi kekuatan dan kelemahan perusahaan dalam berbagai bidang fungsional.

c) MATRIKS CPM

Menurut David (2009) digunakan untuk mengetahui posisi relatif perusahaan dibandingkan dengan perusahaan pesaing.

\section{2) TAHAP PENCOCOKAN}

\section{a) MATRIKS IE}

Menurut Fred R. David (2009), Matriks IE menempatkan berbagai divisi dari suatu perusahaan dalam sembilan sel. Matriks IE didasarkan pada dua dimensi kunci: total nilai IFE yang diberi bobot pada sumbu $X$ dan total nilai EFE yang diberi bobot pada sumbu $Y$.

b) MATRIKS GRAND STRATEGY

Matriks Grand Strategy menurut David (2009) menjadi alat yang populer dalam merumuskan alternatif strategi. Semua perusahaan dapat diposisikan dalam satu dari empat kuadran dalam matriks Grand Strategy. Matriks Grand Strategy didasarkan pada dua dimensi evaluatif, posisi kompetitif dan pertumbuhan pasar. Strategi yang sesuai untuk dipertimbangkan suatu perusahaan terdapat pada urutan daya tariknya dalam masingmasing kuadran pada matriks.

\section{c) MATRIKS TOWS}

Menurut Fred R. David (2009), Matriks TOWS merupakan perangkat pencocokan yang penting untuk membantu manajer mengembangkan empat tipe strategi SO-WO-ST-WT.

\section{3) TAHAP KEPUTUSAN}

\section{MATRIKS QSPM}

Terdapat 6 langkah dalam menyusun matriks QSPM. Langkah-langkah tersebut adalah:

1. Membuat daftar peluang dan ancaman eksternal serta kekuatan dan kelemahan internal kunci perusahaan pada kolom kiri dalam QSPM. Informasi ini harus diambil secara langsung 


\section{Mochamad Ammar Faruq Indrianawati Usman}

dari matriks EFE dan IFE. Minimum sepuluh faktor keberhasilan kunci eksternal dan internal harus dimasukkan dalam QSPM.

2. Berikan bobot untuk masing-masing faktor eksternal dan internal. Bobot ini identik dengan yang ada pada matriks EFE dan IFE. Bobot disajikan dalam kolom persis di samping kanan faktor keberhasilan kunci eksternal dan internal.

3. Evaluasi matriks tahap 2 (pencocokan), dan identifikasi alternatif strategi yang harus dipertimbangkan perusahaan untuk diterapkan. Catat strategi-strategi ini pada baris atas dari QSPM.

4. Tentukan nilai daya tarik (Attractiveness Score-AS) sebagai angka yang mengindikasikan daya tarik relatif dari masing-masing strategi dalam set alternatif tertentu. Nilai AS ditentukan dengan mengevaluasi masing-masing faktor eksternal dan internal kunci. Secara spesifik, nilai daya tarik harus diberikan untuk masing-masing strategi dalam mengidentifikasikan daya tarik relatif dari suatu strategi atas strategi lain, dengan mempertimbangkan faktorfaktor tertentu. Jangkauan nilai daya tarik adalah $1=$ tidak menarik, $2=$ agak menarik, $3=$ cukup menarik, $4=$ sangat menarik.

5. Hitung total nilai daya tarik.

6. Hitung penjumlahan total nilai daya tarik. Tambahkan total nilai daya tarik dalam masingmasing kolom strategi dari QSPM. Penjumlahan total nilai daya tarik mengungkapkan strategi mana yang paling menarik dari setiap set alternatif. Nilai yang lebih tinggi mengidentifikasikan strategi yang lebih menarik, mempertimbangkan semua faktor eksternal dan internal yang relevan yang dapat mempengaruhi keputusan strategis. Tingkat perbedaan antara penjumlahan total nilai daya tarik dari set strategi alternatif tertentu mengindikasikan tingkat kesukaan relatif dari satu strategi di atas yang lainnya.

\section{HASIL DAN PEMBAHASAN}

\section{Profil Perusahaan}

Sebelum mendirikan usaha ini kedua kakak beradik tersebut terlebih dahulu bekerja kepada pamannya sendiri yang usahanya kebetulan bergerak pada bidang yang sama yaitu konveksi dan bekerja sebagai tukang sablon. Kedua kakak beradik ini bekerja disana hampir lima tahun, tapi pada suatu ketika usaha yang didirikan pamannya ini mengalami kebangkrutan sehingga kakak beradik ini kehilangan pekerjaan. Keadaan yang demikian memaksa kedua kakak beradik ini memutar otak untuk dapat mendapatkan pengahasilan. Berbekal ilmu yang didapat selama bekerja disana akhirnya kedua kakak beradik ini memberanikan membuka usaha konveksi sendiri, dengan modal yang serba minim akhirnya konveksi Scissors ini terbentuk.

\section{Visi dan Misi}

Konveksi Scissors sebelumnya belum menulis secara resmi visi misi mereka maka dapat disimpulkan dari wawancara yang dilakukan adalah sebagai berikut:

VISI: 
Konveksi Scissors sebagai produsen produk kaos yang berkualitas kedepannya dengan harga yang bersaing sehingga sehingga mampu maju, berkembang serta bertahan di industri konveksi

MISI:

1. Meyediakan produk dan layanan berkualitas baik

2. Harga produk yang kompetitif

3. Keramahan dan respon cepat dalam pelayanan

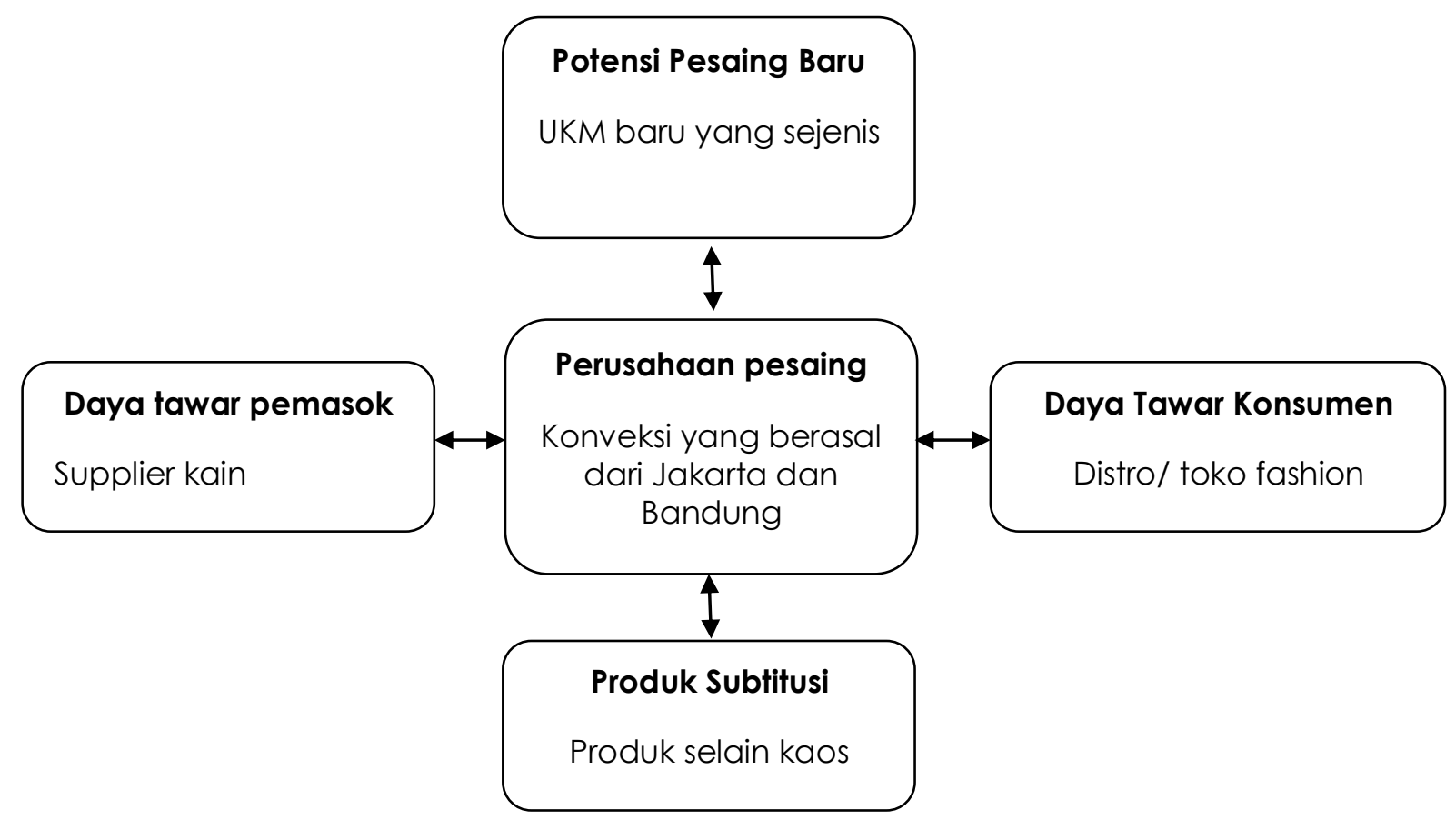

Sumber: hasil wawancara

\section{Gambar 4.2}

Gambar 4.2

\section{Analisis lima model kekuatan porter}

\section{Potensi Pesaing Baru}

Kekuatan para pesaing khususnya pada harga dan desain produk yang kompetitif membuat Konveksi Scissors harus mengimbanginya agar tetap bisa bersaing. Melihat banyak para pelaku bisnis baru yang sejenis mau mengambil resiko dengan memasang harga yang lebih terjangkau demi mendapat pangsa pasar yang baik tapi tidak diimbangi dengan desain dan kualitas produk yang baik membuat perusahaan penting melakukan 


\section{Mochamad Ammar Faruq Indrianawati Usman}

analisa untuk menjaga ritme persaingan dan dapat mengambil solusi dan tindakan demi mengantisipasi kekuatan para pesaing baru.

\section{Daya Tawar Pemasok}

Dalam industri konveksi komponen utama yang dibutuhkan dalam pembuatan kaos adalah kain. Penting bagi perusahaan untuk mencari pemasok kain yang berkualitas karena itu nantinya mempengaruhi produk yang dihasilkan. Dalam hal ini Konveksi Scissors menunjuk salah satu pemasok kain yang dianggap memilik kualitas kain yang baik, demi mendapat pasokan kain yang baik pihak Konveksi Scissors menekan pemasok kain untuk memasok kainnya hanya pada Konveksi Scissors. Dengan melakukan hal demikian membuat Konveksi Scissors mendapatkan pasokan kain yang berkualitas baik dan tidak kekurangan bahan baku. Konveksi Scissors juga harus menjalin komunikasi yang baik dengan pihak pemasok guna menjaga ketersediaan bahan baku dan agar tercipta kerjasama yang saling menguntungkan.

\section{Daya Tawar Konsumen}

Dalam dunia bisnis tawar menawar dari konsumen atau pembeli adalah suatu hal yang tidak dapat dihindari. Kebutuhan kaum muda akan penampilan serta pemenuhan akan kualitas membuat daya tawar dari konsumen semakin kuat. Oleh karena itu, Konveksi Scissors berusaha memenuhi kebutuhan akan penawaran tersebut dengan menciptakan produk yang berkualitas yang mengikuti trend dan tentunya dicari oleh banyak konsumen.

\section{Produk Subtitusi}

Untuk produk pengganti atau subtitusi Konveksi Scissors harus bisa bertahan dan mengantisipasi persaingan tidak langsung dari brand yang terkenal. Banyak sekarang produk-produk pakaian baru yang bermunculan dengan berbagai model yang inovatif serta bentuknya yang modis untuk menarik minat pasar. Konveksi Scissors mengantisipasinya dengan melakukan inovasi pada desain sablon yang unik dan pemilihan bahan baku yang berkualias baik.

\section{Perusahaan Pesaing yang Sudah Ada}

Kesamaan jenis industri, ukuran usaha, dan kesempatan dalam pangsa pasar membuat konveksi yang berasal dari Jakarta dan Bandung menjadi pesaing terberat bagi Konveksi Scissors. Kedua konveksi tersebut berani memasang dengan harga yang rendah demi memuluskan jalan mereka untuk mendapatkan pangsa pasar yang lebih besar, belum lagi mulai bermunculannya usaha-usaha sejenis yang tersebar di berbagai daerah di Indonesia. Ketelitian dalam penciptaan inovasi produk sangat perlu diperhatikan oleh Konveksi Scissors untuk menghadapi pola persaingan seperti ini agar tidak merugikan bagi pihak perusahaan.

\section{Tahap Input}

\section{Matriks EFE (External Factor Evaluation)}


Tabel 4.3

Matriks EFE Konveksi Scissors

\begin{tabular}{|c|c|c|c|c|}
\hline No & Faktor Eksternal Kunci & Bobot & Peringkat & Nilai tertimbang \\
\hline \multicolumn{5}{|c|}{ Peluang } \\
\hline 1 & $\begin{array}{l}\text { Permintaan konsumen akan } \\
\text { produk/desain yang selalu } \\
\text { baru }\end{array}$ & 0,097 & 4 & 0,388 \\
\hline 2 & Banyaknya kaum muda saat ini & 0,040 & 4 & 0,160 \\
\hline 3 & $\begin{array}{l}\text { Bertumbuhnya distro/toko } \\
\text { fashion sebagai peluang } \\
\text { kerjasama }\end{array}$ & 0,046 & 2 & 0,092 \\
\hline 4 & $\begin{array}{l}\text { Kreatifitas desain yang semakin } \\
\text { berkembang }\end{array}$ & 0,139 & 4 & 0,556 \\
\hline 5 & $\begin{array}{l}\text { Tren fashion khususnya kaos } \\
\text { yang selalu berubah }\end{array}$ & 0.092 & 4 & 0,368 \\
\hline \multicolumn{5}{|c|}{ Ancaman } \\
\hline 1 & $\begin{array}{l}\text { Harga pesaing yang lebih } \\
\text { murah }\end{array}$ & 0,044 & 4 & 0,176 \\
\hline 2 & $\begin{array}{l}\text { Meningkatnya pesaing dalam } \\
\text { industri sejenis }\end{array}$ & 0,060 & 4 & 0,240 \\
\hline 3 & $\begin{array}{l}\text { Kondisi ekonomi yang fluktuatif } \\
\text { atau tidak stabil }\end{array}$ & 0,251 & 4 & 1,004 \\
\hline 4 & $\begin{array}{l}\text { Harga bahan baku yang selalu } \\
\text { meningkat }\end{array}$ & 0,197 & 4 & 0,788 \\
\hline 5 & $\begin{array}{l}\text { Nama atau merek pesaing } \\
\text { yang lebih dahulu dikenal }\end{array}$ & 0,034 & 2 & 0,068 \\
\hline Tota & & 1,000 & & 3,840 \\
\hline
\end{tabular}

Sumber: hasil olah data

Dari data tabel 4.3 diatas Konveksi Scissors memiliki nilai 3,840 yang mengindikasikan bahwa Konveksi Scissors merespon sangat baik peluang dan ancaman yang ada di industrinya. Dengan kata lain, Konveksi Scissors sudah mampu memanfaatkan keuntungan dari peluang yang ada dan meminimalkan pengaruh negatif dari ancaman eksternal.

Matriks IFE (Internal Factor Evaluation) 
Tabel 4.6

Matriks IFE Konveksi Scissors

\begin{tabular}{|c|c|c|c|c|}
\hline No & Faktor Internal Kunci & Bobot & Peringkat & Nilai Tertimbang \\
\hline \multicolumn{5}{|c|}{ Kekuatan } \\
\hline 1 & $\begin{array}{l}\text { Desain dan kualitas sablon } \\
\text { yang inovatif }\end{array}$ & 0,179 & 4 & 0,716 \\
\hline 2 & Harga produk kompetitif & 0,127 & 4 & 0,508 \\
\hline 3 & $\begin{array}{l}\text { Kualitas bahan produk yang } \\
\text { baik }\end{array}$ & 0,216 & 4 & 0,864 \\
\hline 4 & $\begin{array}{l}\text { Pelayanan yang sesuai } \\
\text { permintaan konsumen }\end{array}$ & 0,128 & 4 & 0,512 \\
\hline 5 & Loyalitas pekerja yang baik & 0,083 & 4 & 0,332 \\
\hline \multicolumn{5}{|c|}{ Kelemahan } \\
\hline 1 & Kurangnya jumlah SDM & 0,053 & 2 & 0,106 \\
\hline 2 & $\begin{array}{l}\text { Sistem pemasaran yang masih } \\
\text { konvensional atau sederhana }\end{array}$ & 0,052 & 2 & 0,104 \\
\hline 3 & $\begin{array}{l}\text { Kapasitas produksi yang belum } \\
\text { maksimal }\end{array}$ & 0,073 & 1 & 0,073 \\
\hline 4 & $\begin{array}{l}\text { Belum banyak yang mengenal } \\
\text { Konveksi Scissors }\end{array}$ & 0,033 & 2 & 0,066 \\
\hline 5 & Keterlambatan pengiriman & 0,056 & 2 & 0,112 \\
\hline \multicolumn{2}{|c|}{ Total } & 1,000 & & 3,393 \\
\hline
\end{tabular}

Sumber: hasil olah data

Dari tabel 4.6 di atas, dapat diketahui bahwa jumlah nilai faktor internal yang dibobot untuk Konveksi Scissors adalah sebesar 3,393. Hal ini menunjukkan bahwa Konveksi Scissors memiliki posisi internal yang cukup kuat, namun Konveksi Scissors sebaiknya terus berupaya memaksimalkan kekuatan internal usaha dan mengurangi kelemahan-kelemahan internal mereka agar bisa meraih eksistensi dalam industri konveksi pada masa yang akan datang. 
Tabel 4.7

Matriks CPM Konveksi Scissors

\begin{tabular}{|c|c|c|c|c|c|c|c|}
\hline \multirow{2}{*}{$\begin{array}{l}\text { Faktor } \\
\text { Penentu } \\
\text { Keberhasilan }\end{array}$} & \multirow[t]{2}{*}{ Bobot } & \multicolumn{2}{|c|}{ Konveksi Scissors } & \multicolumn{2}{|c|}{ Konveksi Jakarta } & \multicolumn{2}{|c|}{$\begin{array}{l}\text { Konveksi } \\
\text { Bandung }\end{array}$} \\
\hline & & Peringkat & Nilai & Peringkat & Nilai & Peringkat & Nilai \\
\hline Pangsa Pasar & 0,134 & 4 & 0,536 & 4 & 0,536 & 4 & 0,536 \\
\hline Brand & 0,040 & 2 & 0,080 & 3 & 0,120 & 4 & 0,160 \\
\hline $\begin{array}{l}\text { Loyalitas } \\
\text { Pelanggan }\end{array}$ & 0,083 & 4 & 0,332 & 3 & 0,249 & 4 & 0,332 \\
\hline $\begin{array}{l}\text { Kualitas } \\
\text { Produk }\end{array}$ & 0,162 & 4 & 0,648 & 3 & 0,486 & 4 & 0,648 \\
\hline Variasi Produk & 0,134 & 4 & 0,536 & 2 & 0,268 & 2 & 0,268 \\
\hline $\begin{array}{l}\text { Mutu } \\
\text { Pelayanan }\end{array}$ & 0,134 & 4 & 0,536 & 4 & 0,536 & 4 & 0,536 \\
\hline Modal Usaha & 0,101 & 1 & 0,101 & 1 & 0,101 & 4 & 0,404 \\
\hline $\begin{array}{l}\text { Harga yang } \\
\text { Bersaing }\end{array}$ & 0,119 & 4 & 0,476 & 2 & 0,238 & 4 & 0,476 \\
\hline $\begin{array}{l}\text { Ketepatan } \\
\text { waktu } \\
\text { pengiriman }\end{array}$ & 0,046 & 2 & 0,092 & 4 & 0,184 & 4 & 0,184 \\
\hline $\begin{array}{l}\text { Kegiatan } \\
\text { Pemasaran }\end{array}$ & 0,046 & 2 & 0,092 & 4 & 0,184 & 4 & 0,184 \\
\hline Total & 1,000 & & 3,429 & & 3,502 & & 3,728 \\
\hline
\end{tabular}

Sumber: hasil olah data

Dari tabel 4.7 diatas dapat diketahui bahwa Konveksi Scissors memiliki nilai paling kecil diantara dua contoh pesaing yang disebutkan diatas, yaitu Konveksi Jakarta dan Konveksi Bandung. Hal ini menunjukkan kinerja Konveksi Scissors sudah diatas rata-rata industri namun masih belum mampu bersaing dengan perusahaan pesaing yang lebih dahulu eksis, sehingga perlu perbaikan agar perusahaan bisa bersaing lebih dalam industri konveksi ini. 
Mochamad Ammar Faruq

Indrianawati Usman

Tahap Pencocokan

Matriks IE

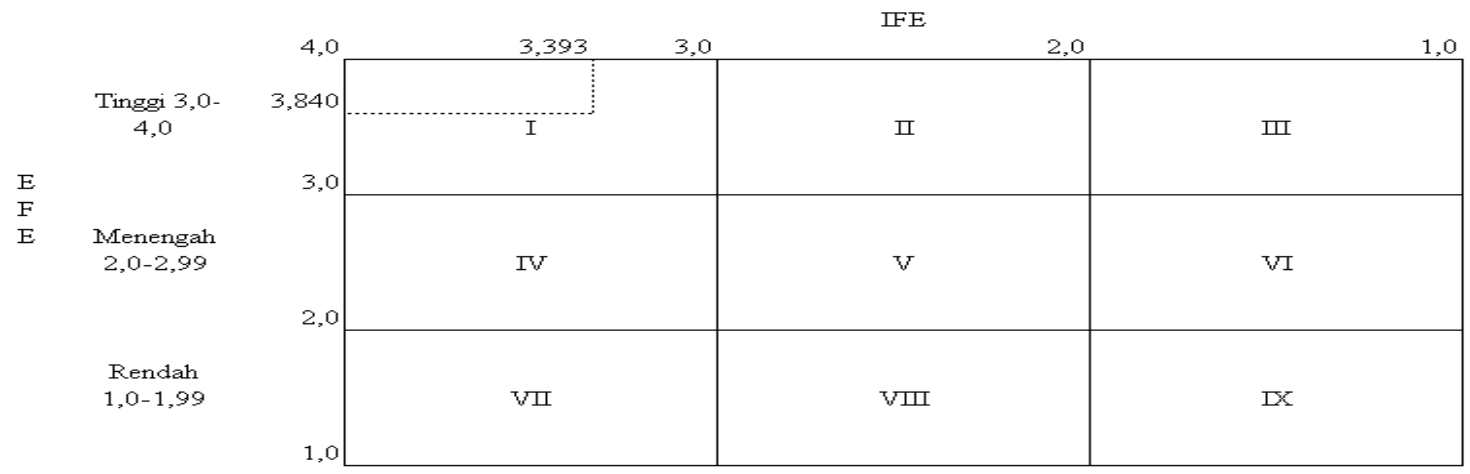

Sumber: hasil olah data

Berdasarkan Matriks IE terlihat bahwa nilai total dari faktor internal perusahaan (IFE) berada pada kuadran I atau rata-rata dan nilai dari total faktor eksternal perusahaan (EFE) juga berada pada kuadran I atau tinggi. Menurut David (2010) Konveksi Scissors berada dalam kondisi growth and build. Strategi yang intensif (strategi penetrasi pasar, pengembangan pasar, dan pengembangan produk) atau strategi yang integratif (strategi integrasi ke belakang, integrasi ke depan, dan strategi horizontal) bisa dapat menjadi kemungkinan alternatif strategi yang tepat bagi perusahaan yang berada dalam kondisi ini.

\section{Matriks Grand Strategy}

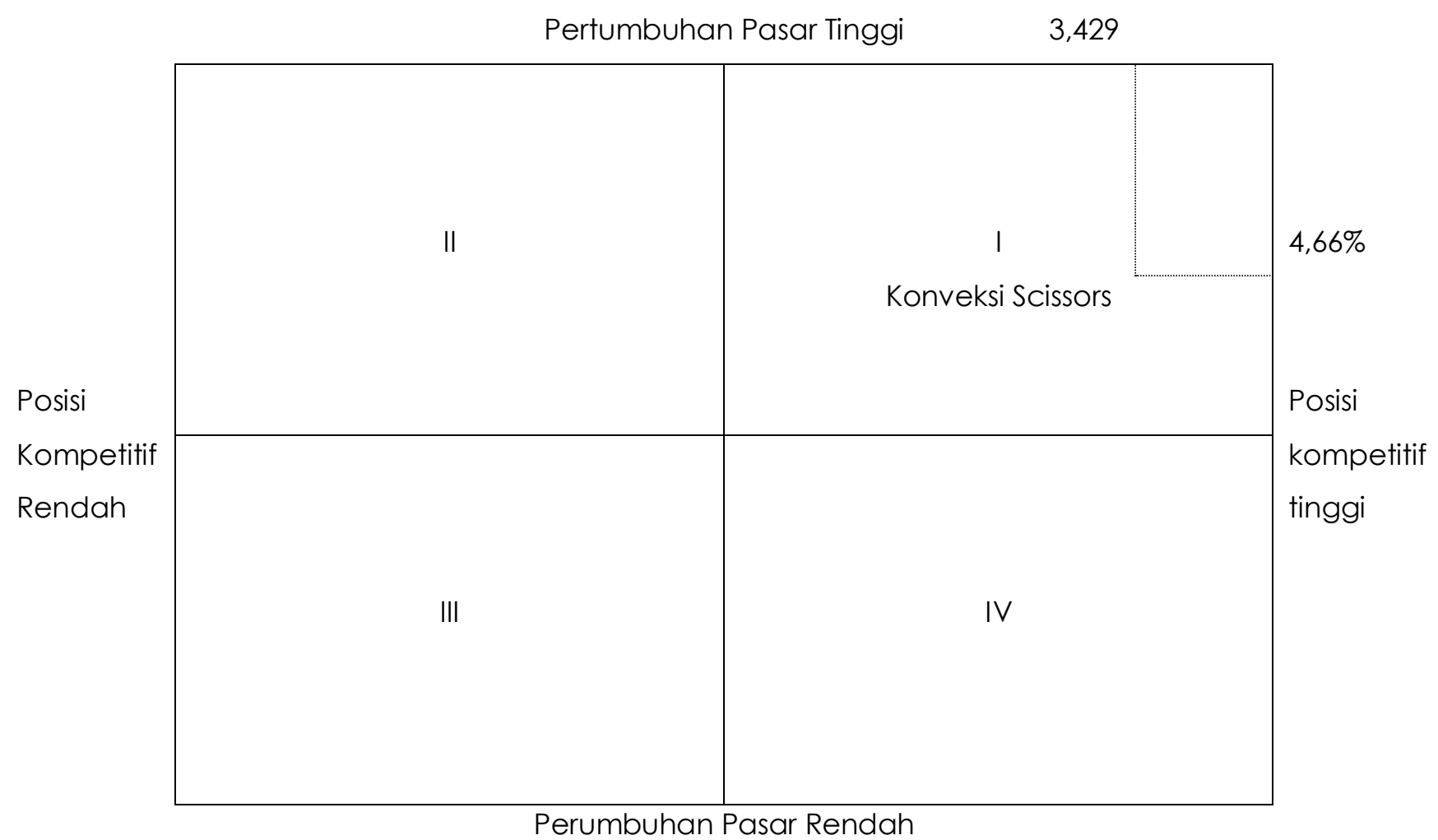

Gambar 4.4

Matriks Grand Strategy Konveksi Scissors 
Dari hasil matriks Grand Strategy, Konveksi Scissors berada pada kuadran I. Menurut David (2010:348) perusahaan yang berada dalam kuadran I memiliki posisi strategis yang sempurna. Konsentrasi pada pasar (penetrasai pasar dan pengembangan pasar) dan produk (pengembangan produk) yang ada saat ini merupakan strategi yang sesuai, jika perusahaan mempunyai kelebihan sumber daya, maka strategi integrasi ke belakang, integrasi ke depan, atau strategi horizontal bisa menjadi strategi yang efektif.

\section{Matriks TOWS}

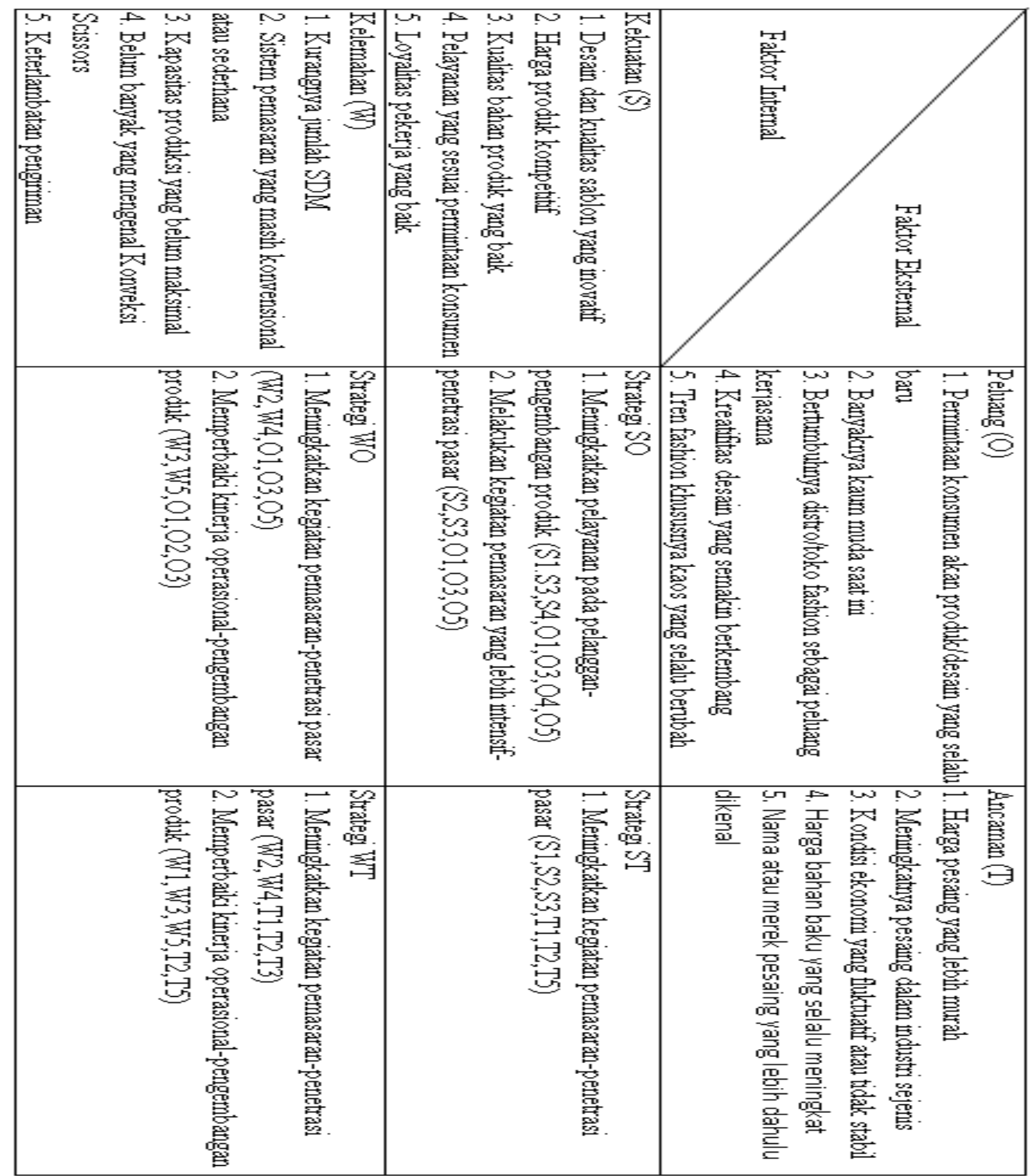

Sumber: hasil olah data

\section{Gambar 4.5}

\section{Matriks TOWS Konveksi Scissors}

Sesuai dengan Matriks IE, Matriks TOWS menemukan 2 alternatif stategi yang sesuai dengan kondisi Konveksi Scissors saat ini, yaitu Penetrasi Pasar dan Pengembangan Produk. 
Mochamad Ammar Faruq

Indrianawati Usman

\section{Matriks QSPM}

\begin{tabular}{|c|c|c|c|c|c|}
\hline \multirow[t]{2}{*}{ Faktor Kunci } & \multirow[t]{2}{*}{ Bobot } & \multicolumn{2}{|c|}{ Pengembangan Produk } & \multicolumn{2}{|c|}{ Penetrasi Pasar } \\
\hline & & AS & TAS & $\mathrm{AS}$ & TAS \\
\hline \multicolumn{6}{|l|}{ Peluang: } \\
\hline 1. Permintaan konsumen akan produk/desain yang selalu barn & 0.097 & 3 & 0.291 & 3 & 0.291 \\
\hline 2. Banyaknya kaum muda saat ini & 0.04 & 2 & 0.08 & 3 & 0.12 \\
\hline 3. Bertumbuhnya distro/toko fashion sebagai peluang kerjasama & 0.046 & 3 & 0.138 & 3 & 0.138 \\
\hline 4. Kreatifitas desain yang semakin berkembang & 0.139 & 3 & 0.417 & 3 & 0.417 \\
\hline 5. Tren fashion khususnya kaos yang selalu berubah & 0.092 & 3 & 0.276 & 3 & 0.276 \\
\hline \multicolumn{6}{|l|}{ Ancaman: } \\
\hline 1. Harga pesaing yang lebih murah & 0.044 & 3 & 0.132 & 3 & 0.132 \\
\hline 2. Meningkatnya pesaing dalam industri sejenis & 0.06 & 3 & 0.18 & 2 & 0.12 \\
\hline 3. Kondisi ekonomi yang fluktuatif atau tidak stabil & 0.251 & 3 & 0.753 & 2 & 0.502 \\
\hline 4. Harga bahan baku yang selalu meningkat & 0.197 & 2 & 0.394 & 2 & 0.394 \\
\hline 5. Nama atau merek pesaing yang lebih dahulu dikenal & 0.034 & 3 & 0.102 & 4 & 0.136 \\
\hline \multicolumn{6}{|l|}{ Kekuatan: } \\
\hline 1. Desain dan kualitas sablon yang inovatif & 0.179 & 3 & 0.537 & 3 & 0.537 \\
\hline 2. Harga produk kompetitif & 0.127 & 3 & 0.381 & 4 & 0.508 \\
\hline 3. Kualitas bahan produk yang baik & 0.216 & 3 & 0.648 & 3 & 0.648 \\
\hline 4. Pelayanan yang sesuai permintaan konsumen & 0.128 & 3 & 0.384 & 3 & 0.384 \\
\hline 5. Loyalitas pekerja yang baik & 0.083 & 2 & 0.166 & 2 & 0.166 \\
\hline \multicolumn{6}{|l|}{ Kelemahan: } \\
\hline 1. Kurangnya jumlah SDM & 0.053 & 2 & 0.106 & 2 & 0.106 \\
\hline 2. Sistem pemasaran yang masih konvensional atau sederhana & 0.052 & 3 & 0.156 & 4 & 0.208 \\
\hline 3. Kapasitas produksi yang belum maksimal & 0.073 & 3 & 0.219 & 3 & 0.219 \\
\hline 4. Belum banyak yang mengenal Konveksi Scissors & 0.033 & 1 & 0.033 & 4 & 0.132 \\
\hline 5. Keterlambatan pengiriman & 0.056 & 2 & 0.112 & 1 & 0.056 \\
\hline Total & & & 5.505 & & 5.49 \\
\hline
\end{tabular}

Sumber: hasil olh data

\section{Gambar 4.6}

\section{Matriks QSPM Konveksi Scissors}

Berdasarkan tabel matriks QSPM Konveksi Scissors di atas, terlihat bahwa strategi pengembangan produk memiliki total nilai daya tarik sebesar 5,505. Nilai ini lebih tinggi tipis disbanding dengan total nilai daya tarik strategi penetrasi pasar dengan nilai 5,490. Pengembangan produk yang dimaksud adalah variasi dan inovasi produk yang dihasilkan. Desian dan model kaos yang bervariasi mengikuti perkembangan jaman saat ini serta sesuai dengan permintaan pelanggan. Hal ini menunjukkan bahwa strategi pengembangan produk lebih baik diterapkan oleh Konveksi Scissors untuk dapat meningkatkan daya saing dan eksisensi di dalam industri konveksi saat ini. 


\section{Jurnal Manajemen Teori dan Terapan \\ Tahun 7. No. 3, Desember 2014}

\section{ANALISIS EKSTERNAL DAN INTERNAL}

Berdasarkan analisis matriks EFE kondisi ekonomi yang fluktuatif atau tidak stabil memiliki bobot yang lebih tinggi artinya Konveksi Scissors merespon lebih kondisi ekonomi yang terjadi saat ini, sedangkan pada peluang kreatifitas desain yang semakin berkembang memiliki bobot yang lebih tinggi artinya Konveksi Scissors memanfaatkan dengan baik peluang tersebut dengan menciptakan inovasi desain yang diharapkan oleh pelanggan.

Berdasarkan analisis matriks EFE kelemahan terbesar terdapat pada kapasitas produksi yang belum maksimal dikarenakan sumber daya yang dimiliki masih terbatas. Disisi lain kekuatan terbesar adalah kualitas bahan produk yang baik. Melihat kondisi tersebut yaitu keterbatasan kapasitas produks coba ditanggulangi oleh Konveksi Scissors dengan menciptakan produk yang berkualitas. Pemilihan supplier dan bahan baku yang digunakan sangat diperhatikan demi dapat menghasilkan suatu produk yang diminati konsumen dan tentu saja berkualitas baik.

Seperti yang telah disebutkan bahwa Konveksi Scissors dengan sangat baik merespon peluang dan ancaman yang ada di industrinya atau dengan kata lain telah mampu secara efektif menarik keuntungan dari peluang yang ada dan meminimalisir pengaruh ancaman eksternal.

\section{ALTERNATIF STRATEGI OPERASI}

Berdasarkan hasil startegi bisnis yang telah disebutkan diatas yaitu pengembangan produk antara lain variasi dan inovasi produk maka alternatif strategi yang sesuai untuk Konveksi Scissors berdasarkan buku Operations Management Roger G Schroeder adalah adalah strategi kedua yaitu strategi Inovator Produk (Product Innovator).

Tabel 4.8

\section{Alternatif strategi operasi Konveksi Scissors}

\begin{tabular}{|l|l|}
\hline \multirow{2}{*}{ Kondisi pasar } & \multicolumn{1}{|c|}{ Strategi B } \\
\cline { 2 - 3 } & $\begin{array}{l}\text { Persaingan yang ketat terutama variasi produk dalam industri } \\
\text { konveksi membuat Konveksi Scissors ikut menciptakan variasi-variasi } \\
\text { pada produknya, mulai dari warna lengan dan badan kaos yang } \\
\text { dibuat berbeda, ukuran lengan yang dibuat lebih panjang, gambar } \\
\text { desain sablon yang dibuat semakin variatif dan bentuk kerah kaos } \\
\text { dibuat model V yang berkancing dan lain-lain. Desain dan bahan } \\
\text { kaos yang dikerjakan pun sesuai dengan apa yang diminta } \\
\text { konsumen. Pelanggan yang menginginkan kaos dengan bahan dan } \\
\text { desain yang bagus dapat dikerjakan oleh konveksi Scissors. Usulan }\end{array}$ \\
\hline
\end{tabular}




\begin{tabular}{|c|c|}
\hline & $\begin{array}{l}\text { operasi dalam kondisi pasar untuk Konveksi Scissors adalah volume } \\
\text { produksi yang kecil tapi dapat memenuhi permintaan pasar, karena } \\
\text { dengan begitu konveksi Scissors dapat meningkatkan fleksibilitas } \\
\text { pemenuhan kebutuhan konsumen saat ini. }\end{array}$ \\
\hline Tujuan operasi & $\begin{array}{l}\text { Permintaan konsumen akan variasi model kaos semakin beragam } \\
\text { dan bermacam-macam. Permintaan yang beragam inilah yang } \\
\text { ditanggapi serius oleh konveksi Scissors saat ini. Misal ada konsumen } \\
\text { yang ingi order kaos dan mereka memiliki desain dan bentuk } \\
\text { kaosnya sendiri seperti apa, ada variasi atau tidak serta kaos } \\
\text { tersebut harus selesai dalam waktu yang tela disepakati } \\
\text { sebelumnya. Dalam proses pengerjaan kaos yang sebanyak } 1500 \\
\text { kaos biasanya dalam waktu seminggu kaos tersebut bisa untuk } \\
\text { dikirim. Konveksi Scissors berusaha mewujudkan apa yang dinginkan } \\
\text { konsumen tersebut. Masalah harga konsumen berani membayar } \\
\text { lebih asal prosuk pesanannya dapat dipenuhi oleh konveksi Scissors. } \\
\text { Tapi semua itu masih belum diimbangi dengan ketepatan } \\
\text { pengiriman pesanan kepada pelanggan dikarenakan sering } \\
\text { molornya pada waktu proses penjahitan kaos. Pegawai yang terlalu } \\
\text { santai dalam proses pengerjaan menjadi penyebabnya, sehingga } \\
\text { deadline pengiriman tidak dapat terpenuhi. Usulan operasi pada } \\
\text { Konveksi Scissors untuk tujuan operasi ini adalah pengiriman } \\
\text { pesanan dilakukan secara tepat waktu yang sesuai dengan } \\
\text { permintaan konsumen karenan dengan begitu tidak akan membuat } \\
\text { konsumen kecewa dan dapat menjaga loyalitas pelanggan itu } \\
\text { sendiri nantinya. }\end{array}$ \\
\hline $\begin{array}{l}\text { Keunggulan khusus } \\
\text { operasi }\end{array}$ & $\begin{array}{l}\text { Desain gambar dan variasi produk menjadi keunggulan dari } \\
\text { Konveksi Scissors. Pengerjaan yang sesuai dengan permintaan } \\
\text { konsumen ditanggulangi oleh Konveksi Scissors. Desain gambar } \\
\text { yang dihasilkan bermacam-macam dan sebisa mungkin tidak } \\
\text { meniru dari yang sudah ada sebelumnya. Tapi produk Konveksi } \\
\text { Scissors sendiri masih belum banyak yang mengetahui karena } \\
\text { kurangnya pemasaran yang dilakukan oleh pihak Konveksi Scissors. } \\
\text { Pesanan yang selama ini diterima sebagian besar berasal dari } \\
\text { pelanggan-pelanggan lama yang telah mengenal Konveksi Scissors. } \\
\text { Usulan dalam keungguan khusus operasi untuk Konveksi Scissors } \\
\text { adalah pengenalan produk baru yang lebih intensif melalui kerja } \\
\text { sama tim yang baik. Beberapa hal yang dapat dilakukan dalam }\end{array}$ \\
\hline
\end{tabular}




\begin{tabular}{|l|l|}
\hline Kebijakan Operasi & $\begin{array}{l}\text { menunjang kegiatan pengenalan produk ini adalah sering mengikuti } \\
\text { kegiatan pameran UMKM, ikut serta dalam acara tahunan } \\
\text { berkumpulnya para vendor kaos seperti Indie Clothing yang baru } \\
\text { saja dilaksanakan. } \\
\text { Sentralisasi proses produksi yang dilakukan seperti proses cutting } \\
\text { kain, desain gambar kaos, penyablonan, penjahitan kaos sampai } \\
\text { proses packing produk yang siap jual tersebut membantu konveksi } \\
\text { Scissors dalam melakukan pengendalian proses produksi sehingga } \\
\text { meminimalisir terjadinya cacat produk dan persediaan barang yang } \\
\text { selalu terkendali. Pemeriksaan secara rutin yang dilakukan tersebut } \\
\text { membuat kualitas produk yang dihasilkan tetap terjaga. Pemilihan } \\
\text { suplier khususnya kain yang menjadi bahan dasar pembuatan kaos } \\
\text { sangat diperhitungkan. Pertimbangan kualitas dan harga } \\
\text { berdasarkan jenis kain serta ketepatan pengiriman menjadi tolak } \\
\text { ukur pemilihan tersebut. } \\
\text { Usulan operasi untuk kebijakan operasi bagi konveksi Scissors adalah } \\
\text { mengembangkan bisnisnya dengan mencoba menciptakan suatu } \\
\text { produk dengan harga jual tinggi atau kaos yang bertaraf premium, } \\
\text { jadi tidak hanya mengerjakan pesanan dari konsumen saja. Selain } \\
\text { itu Konveksi Scissors harus merekrut pekerja yang berketerampilan } \\
\text { tinggi khususnya yang ahli dalam desain grafis karena hal itu dapat } \\
\text { membantu Konveksi Scissors dalam penciptaan variasi gambar yang } \\
\text { semakin inovatif dan menarik. }\end{array}$ \\
\hline
\end{tabular}

\section{INTREPERTASI HASIL PENELITIAN}

Berdasarkan hasil yang dapat dilihat dari pengolahan data melalui Matriks QSPM yang merupakan tahap akhir dalam kerangka penyusunan strategi yang komprehensif, yakni tahap keputusan, terlihat bahwa strategi pengembangan produk memiliki nilai yang lebih tinggi dari strategi penetrasi pasar. Strategi ini cocok digunakan karena tinggkat perekonomian dan perdagangan saat ini telah berkembang pesat serta kebutuhan masyarakat akan produk kaos dengan desain yang inovatif dan berkualitas dengan harga yang terjangkau serta menjamin kepuasan pelanggan meningkat. Oleh karena itu Konveksi Scissors seharusnya dapat memanfaatkan hal tersebut sebagai sarana dalam mengembangkan dan memperbaiki pelayan dan kualitas produk mereka.

Sedangkan dilihat dari alternatif strategi operasi tersebut Konveksi Scissors lebih menekankan pada inovasi desain dan variasi produk. Dalam kasus seperti ini bagian operasi lebih ditekankan pada variasi dan inovasi produk serta fleksibilitas pemenuhan kebutuhan konsumen. Termasuk dalam kebijakan operasi adalah pemakaian tim dalam merancang 


\section{Mochamad Ammar Faruq Indrianawati Usman}

produk baru dan cepat beradaptasi dengan keinginan konsumen serta penggunaan pekerja yang berketerampilan tinggi.

\section{SIMPULAN DAN SARAN}

\section{Simpulan}

1. Peluang Konveksi Scissors yang teridentifikasi yaitu berupa permintaan konsumen akan produk/desain yanng selalu baru, banyaknya kaum muda saat ini, bertumbuhnya distro/toko fashion sebagai peluang kerjasama, kreatifitas desain yang semakin berkembang, tren fashion khususnya kaos yang selalu berubah. Sedangkan Ancaman Konveksi Scissors berupa harga pesaing yang lebih murah, meningkatnya pesaing dalam indusri sejenis, kondisi ekonomi yang fluktuatif atau tidak staabil, harga bahan baku yang selalu meningkat dan nama atau merek pesaing yang lebih dahulu dikenal.

2. Kekuatan Konveksi Scissors yang teridentifikasi meliputi desain dan kualitas sablon yang inovatif, harga produk kompetitif, kualitas bahan produk yang baik, pelayanan yang sesuai permintaan dan loyalitas pekerja yang baik. Sedangkan Kelemahan Konveksi Scissors antara lain kurangnya jumlah SDM, sistem pemasaran yang masih konvensional atau sederhana, kapasitas produksi yang belum maksimal, belum banyak yang mengenal Konveksi Scissors dan keterlambatan pengiriman.

3. Berdasarkan hasil pengolahan pada tahap akhir menggunnakan matriks QSPM, alternatif strategi bisnis yang sesuai dengan Konveksi Scissors adalah pengembangan produk untuk desain dan inovasi. Dalam strategi ini Konveksi Scissors sebaiknya memperbaiki produk yang sudah ada dan mengembangkan yang baru dengan harga murah dalam upaya meningkatkan penjualan.

4. Alternatif strategi operasi Konveksi Scissors yang sesuai adalah strategi inovasi dan variasi produk serta fleksibilitas dan ketepatan waktu pengiriman untuk memenuhi permintaan konsumen. Sedangkan kebijakan operasi adalah pemakaian tim dan partisipasi konsumen dalam mendesain dan merancang produk baru dan cepat beradaptasi terhadap perubahan serta penggunaan pekerja yang berketerampilan tinggi.

\section{Saran}

1. Melakukan evaluasi secara berkala terhadap kualitas proses bisnis perusahaan. Proses bisnis yang berkualitas mampu menghasilkan jasa yang berkualias pula dan begitu juga sebaliknya. Perusahaan mungkin bisa mengembangkan tools seperti QFD (Quality Function Deployment). QFD merupakan alat perencanaan yang digunakan untuk memenuhi harapan pelanggan terhadap suatu produk atau jasa. Implementasikan QFD secara tepat dapat meningkatkan pengetahuan perusahaan terhadap produktivitas dan kualitas produk, efisiensi biaya serta perubahan dan pengembangan produk yang diperlukan seiring dengan kemajuan jaman dan permintaan konsumen. 


\section{Jurnal Manajemen Teori dan Terapan \\ Tahun 7. No. 3, Desember 2014}

2. Melakukan modernisasi sistem dan teknologi yang digunakan. Sistem manual yang selama ini masih digunakan sebaiknya ditinggalkan. Mengingat teknologi informasi yang berkembang pesat saat ini, hal itu sebaiknya dimanfaatkan dengan baik oleh perusahaan dalam mendukung dan memperbaiki proses bisnis perusahaan serta meningkatkan kepuasan pelanggan.

3. Membuat website perusahaan yang berfungsi sebagai alat promosi dan komunikasi dengan konsumen serta sebagai layanan customer service untuk menanggapi keluhan, saran serta kritik dari pelanggan. Keluhan, saran serta kritik dari pelanggan sangat penting dalam membangun dan memperbaiki perusahaan serta meningkatkan eksistensi perusahaan dalam industri konveksi yang ketat.

4. Mengembangkan bisnis dengan menciptakan produk dengan kualitas premium, mengingat minat anak muda terhadap produk kaos premium meningkat seiring dengan sering diselenggarakannya indie clothing expo dimana itu tempat berkumpulnya para produsen kaos premium untuk menjual dan mengenalkan produknya.

5. Membuka toko fashion sendiri untuk mengenalkan produk mereka, selain itu bisa bertemu langsung dengan konsumen akhir dan memahami keinginan konsumen itu sendiri.

\section{Daftar Pustaka}

Barney, Jay B, William S. Hesterly, 2008. Strategic Managemen and Competitive Advantage, Second edition.

Chase, et all., 2001. Schroeder., 2000. And Ward et all., 1989. Dikutip dalam Jurnal Edi Suroso Model Integrasi Lingkungan Bisnis-Strategi Operasi-Kinerja Perusahaan: Studi Empiris Pada Perusahaan Manufaktur Menengah Besar di Tasikmalaya, Jurnal Siasat Bisnis Vol. 13 No. 1 April 2009.

Daft, Richard L, 2002. Manajemen. Edisi kelima Jilid satu. Jakarta: Erlangga

David, Fred R., 2012. Strategic Management Concept and Cases

Faruq, Mochamad Amar dan Indrianawati Usman, 2015. Penyusunan Strategi Bisnis dan

Strategi Operasi Usaha Kecil dan Menengah Pada Perusahaan Konveksi Scissors di Surabaya, Program Studi S1 Manajemen Universitas Airlangga, 161.

Flahrety, T., 1996. Global Operation Management, McGraw Hill - International Edition. Hariadi, Bambang, 2007. Strategi Manajemen. Jakarta: Bayumedia Publishing.

Hitt, Michael A. et all, 2001. Strategic Management Competitiveness and Globlization,

Canada: Cengange Lerning.

http://www.depkop.go.id (diakses tanggal 5 Maret 2014)

Hunger, J. David and Thomas Wheelan., 2003. Manajemen Strategis, Penerjemah Andi:

Yogyakarta.

Kaplan and Norton., 2008. The Execution Premium: Linking Strategy to Operation for Competitive, Boston University. 


\section{Mochamad Ammar Faruq \\ Indrianawati Usman}

Krawjesky, L.J., \& Ritzman, L.P. 2002. Operation Management: Strategy and Analysis, Sixth Edition, Prentice Hall International, Inc

Kristianti, Mariana., 2012. Peran Strategis Usaha Kecil Menengah Dalam Pembangunan Nasional. Majalah IImiah Informatika Vol. 3 No. 1 Januari 2012

Moleong, Lexi., 1998. Metode Penelitian Kualitatif, PT. Dermaga Rostakarya, Bandung.

Nahmanto, Nur Pradana., 2013. Perumusan Strategi Bisnis pada Usaha Kecil dan Menengah (Studi pada Dea Cake Bakery), Skripsi S1 Manajemen, Universitas Brawijaya.

Pearce II., Jhon A, and Richard Robinson., 2008. Manajemen Strategik Formulasi Implementasi dan Pengendalian.

Porter, M. E., 2008. The Five Competitive Force That Shape Strategy January 2008, Harvard Business Review.

Purwanti, Dewi., 2008, Penggunaan Analisis SWOT dalam Kompetitif Bisnis, Jurnal Bisnis Manajemen.

Rahmana, Arif, 2009, Peranan Teknologi Informasi Dalam peningkatan Daya Saing Usaha Kecil Menengah, Seminar Nasional Aplikasi Teknologi Informasi (SNATI 2009), ISSN: 1907-5022, Yogyakarta

Rencana Strategis Kementrian Koperasi dan Usaha Kecil dan Menengah Repubilk Indonesia Tahun 2012-2014

Schroeder, Roger R., 1989. Operation Management: Decision Making in the Operation Function, McGraw Hill - Internasional Edition.

Sugiyono., 2003, Metode Penelitian Bisnis.

Suroso, Edi., 2005. Model Integrasi Lingkungan Bisnis-Strategi Operasi-Kinerja Perusahaan, Studi Empiris Pada Perusahaan Manufaktur Menengah Besar di Tasikmalaya, Jurnal Siasat Bisnis Vol. 13 No. 1 April 2009.

Tunggal, Amin Wijaya., 2004. Manajemen Strategik, Harvindo.

Widjajani dan Yudoko, G., 2010. Strategi Operasi Industri Kecil yang Berkeunggulan Kompetitif: Kasus pengusaha Sepatu Sentra Industri Kecil Cibaduyut Bandung, Jurnal Manajemen Teknologi Vol. 9 No. 22010 